\title{
"Tratado" e Exercício de ser criança: a infância entre versos, rimas e tintas Penha Lucilda de Souza Silvestre ${ }^{1}$ Alice Áurea Penteado Martha ${ }^{2}$ \\ O homem seria metafisicamente grande se a criança fosse seu mestre.
}

Sören Kierkegaard

O texto poético, de modo geral, mantém uma característica peculiar, ao abordar temas que fazem parte do universo da criança e do jovem, pois dialoga com a realidade próxima de seu leitor, sobretudo ao se referir às questões que dizem sobre as emoções, as angústias, as sensações e os sonhos. O poema destinado ao público em pauta é escrito em uma linguagem simples, lúdica e bem elaborada, marcada por vários recursos poéticos, como as rimas, os ritmos, as figuras de linguagem, a sonoridade e os recursos visuais. Essa organização linguística instiga a participação do leitor, no texto, reforçada pelo experimentalismo com a imagem visual, sendo responsável pela coesão e completude do poema.

A poesia é um gênero literário que lida com a palavra de forma metafórica, caracterizando-se pela subjetividade e pela simplicidade e, às vezes, configurando-se como aparentemente objetiva. Assim, a constituição de um poema se dá pelo ritmo, pela rima e pela métrica. Apresenta sensações e emoções, uma vez que leva o leitor a experimentar uma magia advinda da palavra que se faz poesia, porque esta pode multiplicar-se em sentidos diversos, em função do aspecto polissêmico que cada expressão pode conter, somando-se aos diferentes olhares dos leitores.

Nesse sentido, a poesia também se instaura pela imagem e pelo som. As palavras são signos verbais que apresentam um significado e um significante, traduzem diferentes sensações decorrentes de sua constituição linguística. Salienta Nelly Novaes Coelho: "Poesia é também imagem e som" (Coelho, 2000, p. 222). Dessa maneira, o jogo poético que se dá pela imagem (metáforas, alegorias, metonímias) e pela

\footnotetext{
${ }^{1}$ Doutora em letras e professora da Universidade Estadual de Jacarezinho, Jacarezinho, PR, Brasil. E-mail: penhasilvestre@uol.com.br

${ }^{2}$ Doutora em letras e professora da Universidade Estadual de Maringá (UEM), Maringá, PR, Brasil. E-mail: apmartha@uol.com.br
} 
sonoridade (ritmos e rimas) provoca no leitor sensações diversas, levando-o a experimentar emoções peculiares, visto que a poesia "entra pelo ouvido e fica no coração" (Paes, 2001, p. 19). A obra literária, por conseguinte, se realiza na intersecção do texto com o leitor.

A poesia tradicional dirigida para a criança e a juventude teve a intenção de levar ao destinatário o conhecimento ou alguma maneira de aprendizado para aplicá-lo às situações do cotidiano e às atividades práticas de modo racional. Diferentemente, a poesia contemporânea preocupa-se com a ludicidade, o estético e o artístico, pois propicia ao leitor experimentar as palavras poeticamente, enredá-lo nas rimas e nos versos. Isso lhe permite movimentar-se entre as palavras, senti-las na sua forma, imagem e som, numa relação de intimidade e reciprocidade. Nesse sentido, Coelho estabelece uma distinção entre a poesia tradicional e a contemporânea: “A primeira pretendia levar seu destinatário a aprender algo para ser imitado depois; a segunda pretende levá-lo a descobrir algo a sua volta e a experimentar novas vivências que, ludicamente, se incorporarão em seu desenvolvimento mental/existencial"' (Coelho, 2000, p. 223-224, grifos da autora).

À medida que procuramos entender a infância na literatura infantil e juvenil, sobretudo porque ela está atrelada aos mecanismos sociais, políticos e econômicos, já que faz parte de um determinado grupo, é possível perceber as experiências peculiares que a criança vive, os significados que ela produz, porque a criança é autora e atriz de um tempo e está em cena nos espaços familiares, nas escolas e nas ruas, é detentora de uma cultura e de um modo de ser. Ketzer assinala que a criança "carrega consigo uma cultura, concebida simbolicamente na imersão das vivências experimentadas em sua comunidade cognitiva, que lhe fornece um mapa de navegação do qual fará uso ao longo da vida" (Ketzer, 2003, p. 13). Podemos, então, pensar nos aspectos que ultrapassam a vivência familiar e individual, uma vez que estas são atravessadas pelo poder do Estado. Essas questões nos remetem aos aspectos temáticos recorrentes na literatura e na pintura, os quais veiculam valores diversos, porque traduzem uma posição política e ideológica.

Isso nos instiga a elaborar uma concepção da criança, tendo em vista que pretendemos entendê-la no universo literário e plástico. Dessa maneira, compreendemos que essa questão ganha diferentes olhares, porque há um investimento da produção mercadológica. Ou também, conforme assinala Gregorin Filho, ao pensar na criança e no seu 
universo hoje, estamos diante de "um conceito que se construiu do dialogismo, no sentido bakhtiniano do termo, entre textos que se produziram historicamente, ou seja, criança para nossa sociedade é um conceito histórico e dialético da etapa de desenvolvimento do ser humano" (Gregorin Filho, 2009, p. 40). Assim, passamos a entender a criança enveredada nas tramas da poesia e como se dá a sua concepção com base no olhar do artista.

A obra de arte, de modo geral, consiste em um evento significativo, visto que o leitor pode não apenas vivenciar diferentes mundos ficcionais, como também recuperar e articular as redes intertextuais, no ato da leitura. Dessa maneira, há a possibilidade de repensar a sua própria experiência e as condições sociais em que está inserido. Nesse sentido, o nosso objetivo é realizar um percurso no universo poético, a partir da leitura dos textos Exercício de ser criança (1999), de Manoel de Barros, e Um pequeno tratado de brinquedos para meninos quietos (2009), de Selma Maria Kuasne, associando-os à produção plástica de Candido Portinari "Meninos soltando pipa" (1932), "Crianças brincando" (1938) e "Meninos brincando" (1955), porque essas obras nos ajudam a repensar como se dá a representação e a constituição da infância, na arte, de sorte a entendê-la nas tramas da poesia e da pintura, assim como o ato de brincar, em um processo dialético.

\section{A infância entre versos e rimas}

Verbo ser

Que vai ser quando crescer?

Vivem perguntando em redor. Que é ser?

É ter um corpo, um jeito, um nome?

Tenho os três. E sou?

Tenho de mudar quando crescer? Usar outro nome, corpo e jeito?

Ou a gente só principia a ser quando cresce?

É terrível, ser? Dói? É bom? É triste?

Ser; pronunciado tão depressa, e cabe tantas coisas?

Repito: Ser, Ser, Ser. Er. R.

Que vou ser quando crescer?

Sou obrigado a? Posso escolher?

Não dá para entender. Não vou ser.

Vou crescer assim mesmo.

Sem ser Esquecer.

Carlos Drummond de Andrade 
A poesia é um processo comunicativo e exige a presença do receptor. Este passa a ter uma visão diferente do mundo que o cerca, ao adentrar nesse universo. O poeta, por sua vez, traduz o sentimento do mundo, nomeia e reconhece o seu espaço pela linguagem. Afinal, o "poeta é doador de sentimento" (Bosi, 2000, p. 163). Ele diz sobre os mais variados estados psíquicos da alma, da condição social e política de seu tempo, das ideias filosóficas e ideológicas que perpassam os mais diversos grupos. Assim, a poesia é indispensável ao homem, por levá-lo a atitudes reflexivas, à aquisição do saber e a um olhar crítico diante da complexidade do mundo, fazendo-o experimentar um momento de pura fruição. Dessa maneira, a poesia pode ser um instrumento consciente de revelação política, emocional e intelectual. $\mathrm{O}$ universo literário é levado à esfera do leitor, e este, ao identificar-se com o eu lírico, distancia-se de sua subjetividade, participa de uma outra vivência humana e, simultaneamente, pode incorporar ou negar a sua experiência.

Sabemos que a fantasia é fundamental para todas as pessoas, porque todos sonhamos durante as horas de vigília ou não. A literatura, por seu turno, colabora para que o leitor possa vivenciar a ficção. Nessa perspectiva, no texto "O menino que carregava água na peneira", parte do livro Exercícios de ser criança (1999), Manoel de Barros traz ao leitor poemas aparentemente marcados pelo nonsense ou absurdo. $\mathrm{O}$ eu lírico anuncia: "Tenho um livro sobre águas e meninos" (1999) - e afirma que gostou mais de um menino "que carregava água na peneira" (Barros, 1999, s.p.). A mãe do menino, suficientemente boa (expressão de Winnicott, 1975, ao dizer de uma mãe boa e continente), assegura que carregar água na peneira "era o mesmo que roubar um vento e sair", mas sair com o vento e mostrar aos irmãos, ou, então, o mesmo que "catar espinhos na água / O mesmo que criar peixes no bolso" (Barros, 1999, s.p.).

O universo poético é representado nesse texto por uma série de imagens, que vão se construindo à medida que são apresentados o modo de ser do menino e o olhar da mãe sobre ele:

O menino era ligado em despropósitos.

Quis mostrar os alicerces de uma casa sobre orvalhos.

A mãe reparou que o menino

Gostava mais do vazio do que do cheio.

Falava que os vazios são maiores

E até infinitos.

Com o tempo aquele menino

Que era cismado e esquisito 
Porque gostava de carregar água na peneira.

Com o tempo descobriu que

Escrever seria o mesmo que carregar água na peneira (Barros, 1999, s.p.).

Notamos que o poeta brinca, inicialmente, com absurdos e despropósitos, mostrando diferentes ângulos dos fatos; por conseguinte, o leitor é capaz de construir uma visão de mundo a partir da organização textual: "Toda obra literária é antes de mais nada uma espécie de objeto construído; e é grande o poder humanizador dessa construção, enquanto construção" (Candido, 1995, p. 246). Freud, por sua vez, explica o papel do artista, afirmando que ele sabe dar forma "a seus devaneios de modo que estes perdem aquilo que neles é excessivamente pessoal e que afasta as demais pessoas, possibilitando que os outros compartilhem do prazer obtido nesses devaneios" (Freud, [1915-1916] 1996, p. 378). Além disso, o artista sabe disfarçar e manter intacta a origem desses devaneios. Freud salienta que o artista:

Possui o misterioso poder de moldar determinado material até que torne imagem fiel de sua fantasia; e sabe, principalmente, pôr em conexão uma vasta produção de prazer com essa representação de sua fantasia inconsciente, que, pelo menos no momento considerado, as repressões são sobrepujadas e suspensas. Se o artista é capaz de realizar tudo isso, possibilita a outras pessoas, novamente, obter consolo e alívio a partir de suas próprias fontes de prazer em seu inconsciente, que para elas se tornaram inacessíveis (Freud, [1915-1916] 1996, p. 378).

Freud chama a atenção para a questão da fantasia, ressaltando a importância da arte, a qual permite ao artista chegar à realidade por meio da criação artística, porque apresenta capacidade de sublimação. $\mathrm{O}$ resultado da produção artística revela uma face da fantasia e da imaginação de seu criador. Assim, com base na invenção criada pelo menino e assegurada pela mãe, deparamo-nos com o fazer literário que impregna as aventuras do menino:

No escrever o menino viu

Que era capaz de ser

Noviça, monge ou mendigo

Ao mesmo tempo.

O menino aprendeu a usar as palavras.

Viu que podia fazer peraltagens com as palavras. 
E começou a fazer peraltagens.

Foi capaz de interromper o voo de um pássaro

Botando ponto final da frase (Barros, 1999, s.p.).

O poeta brinca com a linguagem e a deixa traduzir a imaginação da criança, num processo de identificação, porque ambos - o poeta e o infante - vivem uma descoberta decorrente do envolvimento criativo com as palavras e, por isso, a criança "está atenta à materialidade das palavras; que vê o mundo magicamente, animando seres e coisas, de modo a alimentar a sua fantasia" (Aguiar e Ceccantini, 2012, p. 334).

O menino fazia prodígios.

Até fez uma pedra dar flor!

A mãe reparava o menino com ternura

A mãe falou:

Meu filho você vai ser poeta.

Você vai carregar água na peneira a vida toda.

Você vai encher os

Vazios com as suas

E algumas pessoas

vão te amar por seus

despropósitos (Barros, 1999, s.p.).

Barros apropria-se do universo infantil, cria neologismos, sinestesias, e brinca com a palavra. A poesia auxilia a perceber a criança que dorme dentro do adulto, além de surpreender o olhar materno a acompanhar o menino que consegue carregar água na peneira. Winnicott (1975) sublinha a importância de a mãe suficiente boa, pois ela propicia a adaptação do menino ao espaço em que está inserido e a possibilidade de estabelecer relações interpessoais; o mundo sempre existiu, mas cabe à mãe apresentá-lo. E, então, o menino pode criar. Paralelamente ao ato de escrever, a criatividade é fundamental para sinalizar a existência e estabelecer relações consigo e com o outro, de forma saudável, já que o sujeito se percebe como o autor de suas ações, sabe que pode fazer realizações de diferentes naturezas. Assim, viver de forma criativa perpassa pelo interior e pelo externo. Ademais, esse livre trânsito permite a (re)integração do self, ligado às experiências mais primitivas da criança.

Logo, cada pessoa tem uma forma peculiar de existir, porque isso depende das experiências individuais. Em consequência, a criatividade 
está relacionada à vida e à existência, pois a "criatividade é o fazer que, gerado a partir do ser, indica que aquele que é está vivo. Pode ser que o impulso esteja em repouso; mas, quando a palavra 'fazer' pode ser usada com propriedade, já existe criatividade" (Winnicott, 2005, p. 23, grifos do autor). Entendemos que não se trata de uma vontade ou não de realizar algo, porque a criatividade está ligada às primeiras experiências de vida e é explicada como "a manutenção, através da vida, de algo que pertence à experiência infantil: a capacidade de criar o mundo" (Winnicott, 2005, p. 24). O eu lírico sinaliza a criatividade do menino, ao criar os seus despropósitos e o ambiente que assegura o seu pensar.

Aguiar e Ceccantini assinalam que, na obra de Barros, em análise, está enfatizada "a postura do adulto (capaz de reinaugurar a linguagem, por certo), que concebe uma imagem de infância associada à pureza dos sentimentos mais arcaicos e espontâneos, percebida de fora, de modo adultocêntrico" (Aguiar e Ceccantini, 2012, p. 334). Observam que a "inadequação dos poemas ao leitor previsto pelo livro, daí, decorrente, nesse caso é atenuada pela proposta gráfico-editorial, pela escolha do material, pela disposição do texto e pela qualidade das ilustrações" (Aguiar e Ceccantini, 2012, p. 334). As ilustrações são organizadas a partir de bordados coloridos e alegres, com linhas brilhantes e acetinadas, compostos por várias bordadeiras (Antônia Zulma Diniz, Ângela, Marilu, Martha e Sávia Dumont sobre desenhos de Demóstenes). O conjunto da obra resulta num trabalho criativo, lúdico e estético, que capta a atenção do leitor. Já no texto "A menina avoada", também parte do livro Exercício de ser criança, o eu lírico revisita o passado:

Foi na fazenda de meu pai antigamente.

Eu teria dois anos; meu irmão, nove.

Meu irmão pregava no caixote

Duas rodas de lata de goiabada.

A gente ia viajar.

As rodas ficavam cambaias debaixo do caixote:

Uma olhava para a outra.

$\mathrm{Na}$ hora de caminhar

As rodas se abriam para o lado de fora.

De forma que o carro se arrastava no chão.

Eu ia pousada dentro do caixote

Com as perninhas encolhidas.

Imitava estar viajando (Barros, 1999, s.p.). 
O brincar é uma forma saudável de viver, controlar as ansiedades e reelaborar os conflitos. Já a experiência cultural diz sobre a ampliação "dos fenômenos transicionais e da brincadeira, podendo ser retratada como um depositário das tradições herdadas - intermediário comum da humanidade - onde a mobilização dos indivíduos em prol de um trabalho comum é estabelecida" (Souza, 2011, p. 100). A experiência cultural posiciona-se no ponto intermediário "similar ao espaço potencial das brincadeiras" (Souza, 2011, p. 100). Sendo assim, Winnicott (1975) afirma a existência de uma base de tradição, mas nenhum campo cultural é original.

Pensamos, pois, que o viver criativo acontece quando há uma disponibilidade afetiva materna, por meio da instalação de uma relação amorosa mãe-bebê, marcada pelos valores afetivos, culturais e morais internalizados pelo bebê, advindos dos cuidados e das funções maternas (holding, handling e apresentação de objetos), os quais favorecem o processo de indiferenciação e a confiança no espaço em que está inserido. $O$ brincar, acrescido das condições saudáveis do espaço, permite a formação de uma personalidade integrada, por se tratar de uma atividade curativa, que capacita a criança a elaborar seus conflitos internos.

Assim, é no brincar, "e somente no brincar, que o indivíduo, criança ou adulto, pode ser criativo e utilizar sua personalidade integral; e é somente sendo criativo que o indivíduo descobre o seu self' (Winnicott, 1975 , p. 80). Por isso, o brincar resulta em uma comunicação criativa, aspecto essencial para viver a vida em sua possível totalidade:

Meu irmão puxava o caixote por uma corda de embira.

Mas o carro era diz-que puxado por dois bois.

$[\ldots]$

Meu irmão falava

que eu tomasse cuidado

porque Redomão mão era coiceiro.

[...]

No caminho, antes, a gente precisava

De atravessar um rio inventado.

Na travessia o carro afundou

E os bois morreram afogados.

Eu não morri porque o rio era inventado (Barros, 1999, s.p.). 
Assim, o brincar é um modo que a criança encontra de comunicar os desejos, os anseios e a percepção que tem do mundo e do espaço que a rodeia. $\mathrm{O}$ brincar favorece o contato com os sentimentos que precisam ser elaborados pela criança, porque provoca satisfação e é, portanto, uma estratégia própria dela, universal, a qual comunica algo e propicia o crescimento psíquico. A experiência criativa remete-nos à condição do Ser, ou seja, o sujeito vive e procura encontrar uma forma para dar sentido a sua existência, uma vez que a vida passa por diferentes estágios, dos quais as experiências cotidianas e psíquicas determinam as escolhas e as maneiras de manifestar-se na relação com o outro, com o mundo e consigo mesmo.

A criatividade é fundamental para sinalizar a existência e estabelecer relações consigo mesmo e com o outro, de forma saudável, pois o sujeito se percebe como o autor de suas ações, sabendo que pode fazer realizações de diferente natureza. Vera Teixeira de Aguiar e João Luís Ceccantini (2012) comentam sobre as brincadeiras de crianças recorrentes no texto de Manoel de Barros, que as reaviva a partir de um tempo outro, relembrando as façanhas de um passado remoto.

Exercício de ser criança não é uma tarefa meramente repetitiva, de sorte que exige um desempenho, uma manobra, um movimento e uma prática peculiar que sublinhe algo criativo e elaborado pela criança que brinca com seus pares. $\mathrm{O}$ brincar, no primeiro texto, repassado de cunho metaliterário, remete-nos ao fazer poético; já no segundo, à reinvenção da própria infância.

Nessa mesma linha temática, o texto Um pequeno tratado de brinquedos para meninos quietos, de Selma Maria Kuasne, ilustrado por Anne Vidal e publicado em 2009, é composto por sete textos poéticos: "Os brincares", "Brinquedo-livro", "Brinquedo-terra”, "Brinquedo-bicho", "Brinquedocor", "Brinquedo-brinquedo", "Brinquedo-pensamento". A obra traz, poeticamente, uma série de brincadeiras que enlevam a criança, num processo criativo e natural.

Nos textos de abertura "Brasinha, um menino quieto", "Na barriga da poesia" e "O brincar do sertão", a autora explica a gênese do livro. Em seguida, há a apresentação dos textos poéticos e, ao final, como se fosse uma conclusão, a editora escreve "Fonte de brinquedos e poemas". Nesta última parte, há um álbum de fotografias das diferentes manifestações do brincar. Na contracapa do livro, Manoel de Barros destaca que "é a própria infância da palavra [...]. As crianças quietas estão vivenciando o seu 
primeiro ver, o seu primeiro ouvir, o seu primeiro tocar" (Barros apud Kuasne, 2009, s.p.). E prossegue: "As crianças quietas estão guardando os primeiros conhecimentos do mundo" (Barros apud Kuasne, 2009, s.p.).

A autora, por sua vez, assinala: "Ser um tratado é ser algo olhado, observado, estudado. E também algo que você trata com cuidado" (Kuasne, 2009, p. 8). Conforme o Novo dicionário Aurélio de língua portuguesa (1993), tratado pode ser um contrato, um estudo de algo ou de um objeto desenvolvido acerca de uma ciência ou de uma arte. Em decorrência, temos: "Um tratado de brinquedos pode reunir essas ações juntas para simplesmente mostrar a relação afetiva que temos com esses objetos. E brinquedos para meninos quietos, penso eu, nascem na barriga de uma senhora chamada poesia. E vivem na infância do mundo" (Kuasne, 2009, p. 8). A poesia, para Kuasne, alcança uma conotação além do texto escrito, ganha a dimensão da poeisis que nos remete ao criar. Ela propõe um caminho para a criação e oferece ao leitor a possibilidade de brincar: "Se você quiser brincar de criar estórias com um menino chamado Brasinha, pode começar assim" (Kuasne, 2009, p. 7).

Após a sugestão, ela inicia: "Era uma vez um menino que descobriu que tinha uma rosa no coração. Essa rosa foi crescendo tanto que ele resolveu dividi-la com as pessoas que conhecia, deixando a todos apaixonados pelas Rosas que começavam a crescer em seus corações também" (Kuasne, 2009, p. 7). O vocábulo "rosa" nos remete a Guimarães Rosa, primo de Brasinha. Este é contador de histórias na cidade de Cordisburgo e apresentou a Selma Maria "todas as pessoas, lugares e estórias que estiveram presentes na infância de Joãozinho e que ilustram com as sete cores do arco-íris este trabalho" (Kuasne, 2009, p. 7).

Nas páginas iniciais, há um preâmbulo sobre a relação do brincar com a poesia e a respeito de como se deu a gênese do trabalho da poetisa. $O$ leitor é convidado a participar desse evento. À primeira vista, ele se envolve com os textos poéticos que giram em torno das sensações e o remetem às histórias já conhecidas, como os contos de fadas, sobretudo a personagem Bela Adormecida. A poesia fala sobre a passagem da menina para a fase madura, estende-se aos conflitos edípicos e chega à rivalidade entre a filha e a mãe:

Histórias de maçã envenenam mocinhas [...]

Histórias de maçã

expulsam gente do paraíso (Kuasne, 2009, p. 32). 
No mesmo texto, há a exploração da mítica da criação e da gênese do mundo, sobretudo quando o eu lírico declara que as histórias de maçãs "expulsam gente do paraíso" (Kuasne, 2009, p. 32). De certa maneira, o texto é provocativo, marcado pelo humor.

À medida que Kuasne traz as brincadeiras, ela também esboça a imagem da criança e da infância do sertão, mostrando fatos históricos assimilados por diferentes culturas. Exemplo disso é a alusão a Joana D'Arc e à festa popular do boi, recorrente no Nordeste:

\section{Boi bonito}

Êta, meninos inventeiros!

Como são bagunceiros e arteiros

esses filhos de violeiros, boiadeiros.

Inventam brinquedos nos fogareiros

Outro dia até um sabugo de milho

foi para a fogueira,

brincar de Joana e morrer queimado.

Mas que nada!

Era brincadeira da criançada!

Fazer um boi todo malhado

Era o brinquedo que eles tinham inventado (Kuasne, 2009, p. 42)

Em "Despedida", o eu lírico narra a história de um menino "que gostava de inventar. / Quieto bastante ele era / no pensar e no olhar" (Kuasne, 2009, p. 55). A quietude representa um valor e uma singularidade:

Jeito diferente para tudo

arranjava para brincar.

Brincava de geografia,

brincava de observar.

Nem amigo precisava

na hora de imaginar.

Brincava de construir, brincava de criar.

Várias pontes ele fazia

para formiga passar.

Prendidas lá na pedra,

Proibidas de escapar (Kuasne, 2009, p. 55).

$\mathrm{Na}$ última estrofe, formada por cinco versos, o eu lírico sugere que o leitor descubra dentro de si um brinquedo quieto, porque "dentro de 
cada um / um menino quieto mora" (Kuasne, 2009, p. 55). Essa criança também pode ser entendida além da idade cronológica e estender-se à criança que habita no adulto.

A partir da imagem provocada pela organização da linguagem poética, os textos de Selma Maria Kuasne e de Manoel de Barros instigam-nos a pensar nas telas de Candido Portinari (1903-1962), artista plástico preocupado como o retrato da cultura brasileira, de modo geral, mas também com a infância, a qual recebe cores, linhas, traços de pincéis e tintas multicoloridas. Em consequência, os textos poéticos nos remetem à infância captada pelo artista plástico, que fez da arte de brincar e de jogar um tema muito explorado. Em algumas de suas obras, há a presença do lúdico e da espontaneidade, caracterizando um tempo e um espaço nos quais crianças brincam, aparentemente desprovidas de competitividade, mas ligadas ao ato da criação, mostrando a potencialidade de cada ser e favorecendo a aprendizagem, na relação com o outro.

Nas telas "Meninos soltando pipa" (1932), "Crianças brincando" (1938), "Meninos brincando" (1955), dentre outras, percebemos movimentos espontâneos, pelos traços, das cores e dos elementos que compõem as obras. Portinari retrata a infância e as brincadeiras criadas pelos meninos e meninas, de maneira a relembrar sua própria experiência, enquanto documenta um tempo ou uma história, especialmente uma série de brincadeiras registradas pelos bandos das crianças: espantalho, estilingue, pipa, pião, balanço, ioiô, botão, futebol, pião, bolinha de gude, malabarismos, entre outras. Nesse sentido, o artista elabora uma representação da infância por meio da arte pictórica e propicia uma reflexão crítica, seja do olhar artístico, seja do social, de sorte a provocar novos olhares e alterar o cenário da arte brasileira.

Desse modo, a composição das telas (cores, linhas, perspectivas) permite a criação de sentidos e amplia o significado de ser criança, visto que o receptor se depara com as imagens infantis, as brincadeiras e a cultura de um país, rompendo com fronteiras geográficas. $\mathrm{O}$ receptor, então, percebe o mundo da infância nas imagens de Portinari, cujas pinturas aparecem como expressões e pinceladas marcadas pela poesia, uma vez que registram as impressões e a concepção de ser criança.

Os aspectos temáticos ligados à infância e ao brincar passam pelo texto de Selma Maria Kuasne, Manoel de Barros e Candido Portinari. Esses temas levam-nos a repensar na experiência criativa, no brincar e na poesia, somando-se as intenções políticas e econômicas que 
determinam, às vezes de forma implícita, o lugar de cada um, quer criança, quer adulto. Ao mesmo tempo, é crucial pensar de que crianças estamos falando. Nessa direção, percorremos o texto de Manoel de Barros e encontramos uma infância revivida, caracterizada pela fantasia e pelas brincadeiras criativas entre irmãos e pela presença necessária do papel materno. Selma Maria Kuasne, não diferentemente, registra textos poéticos nos quais os meninos criam os seus brinquedos, em parceria com os vizinhos. Por fim, as telas de Portinari nos remetem à infância no interior de São Paulo, onde meninos soltam pipas, jogam piões e brincam de gangorra, entre outras brincadeiras.

Sabemos que hoje, nos grandes centros das cidades brasileiras, as crianças já não brincam com fantasias e imaginações tais como aquelas encontradas na poesia e na pintura; ao contrário, experimentam outras situações marcadas, às vezes, pela precariedade material: crianças pedem esmolas nas ruas, trabalham em semáforos vendendo balas ou até mesmo param com sacolas vazias, a fim de enchê-las de moedas. Crianças se prostituem, aliviam as dores com diferentes entorpecentes e servem de escravos para uma máfia de traficantes. A rua é o mundo. Essas crianças não têm acesso aos bens produzidos pela indústria cultural, muito menos acesso ao livro. Diferentemente, há outras crianças, de um grupo social mais privilegiado, com acesso aos diferentes objetos culturais produzidos para atender a uma demanda de prazer, interesses educacionais e cotidianos. Elas não têm a rua, mas têm a tela do computador, as academias e as aulas de balé, entre outras atividades dirigidas.

Nesse sentido, pensar a infância e a produção dos bens culturais é algo extremamente delicado. Dessa maneira, espera-se "reafirmar, e não desconsiderar, que os estratos sociais definem, inclusive, um tipo de infância e de infante, cuja cultura estará profundamente marcada (não para o bem ou para o mal) por tais circunstâncias" (Ketzer, 2003, p. 15). Trata-se de um contexto em que notamos os mecanismos de controle e de manipulação das emoções, porque o acelerado e ágil ritmo de novidades mercadológicas acontece em um movimento quase instantâneo, de forma inovadora, dirigida ao público em geral, sobretudo por intermédio dos jogos eletrônicos e brinquedos de toda espécie, voltados para faixa etária definida. Há um mercado consumidor dirigido a uma parcela do público infantil. 
Peter Hunt, em Crítica, teoria e literatura infantil (2010), traz a discussão em pauta e assinala a complexidade da questão. Ele observa que a definição da infância passa pelos aspectos sincrônicos e diacrônicos, ressaltando, por exemplo, que no livro What is a child? (1997), Nicholas Tucker "aproxima características transculturais e diacrônicas da infância. Entre elas se incluem a brincadeira espontânea, a receptividade à cultura vigente, os constrangimentos fisiológicos (em geral, elas são menores e mais fracas que os adultos), e a imaturidade sexual" (Hunt, 2010, p. 91). Hunt acrescenta, ainda, os laços emocionais com adultos, o desenvolvimento cognitivo (concreto ao abstrato), as diferenças perceptivas de atenção e concentração em relação ao adulto. Por isso, a tendência da criança é adaptar-se ao mundo adulto, porque este já apresenta esquemas fixados.

Outro aspecto pontuado por Hunt refere-se à elaboração dos estágios de desenvolvimento da criança postulados por Jean Piaget e discutidos no livro citado de Nicholas Tucker. Os estudiosos observam a dificuldade de generalizar os estágios a todas as crianças, já que se trata de um ser na sua singularidade e que pode diferir da norma, ao responder aos impasses da vida, dos aspectos sociais e culturais; por conseguinte, cada estágio da criança pode apresentar-se de forma diferente. Assim, serão "mais abertas ao pensamento radical e aos modos de entender os textos; serão mais flexíveis em suas percepções de texto. E, como a brincadeira é um elemento natural de seu perfil, verão a linguagem como outra área de exploração lúdica" (Hunt, 2010, p. 92). Desse modo, Hunt enfatiza as diferenças entre a criança e o adulto, sejam as questões ligadas ao conhecimento, sejam as relacionadas às estruturas linguísticas, ao mundo real ou imaginário (fatos e fantasias). Consequentemente, as crianças pertencem "a uma cultura diferente - talvez a uma anticultura ou contracultura" (Hunt, 2010, p. 92).

Esse fato pode dificultar o adulto que trabalha com textos e infância, porque a criança, de modo geral, pertence a uma cultura oral, "o que significa que elas podem apresentar diferentes modos de pensar e lidar com diferentes gêneros textuais" (Hunt, 2010, p. 92). Ao pensarmos a infância, deparamo-nos com impasses, interpretações ambivalentes: o que é da criança e o que é para a criança. Nessa rede de implicações complexas, Hunt assevera: "Tudo isso leva os adultos a criar ou permitir diferentes tipos de infância - o que, em termos sociais, poderia ser mais bem definido como um período de falta de responsabilidade, bem como um desenvolvimento incompleto" (Hunt, 2010, p. 93). 
Já do ponto de vista diacrônico, Hunt assinala que o conceito de infância é "extremamente complexo e mal documentado. No passado, houve considerações radicais sobre a infância, da criança bom selvagem do Romantismo, que está mais próxima de Deus, até a criança gerida má em consequência do pecado original" (Hunt, 2010, p. 93). Nos países marcados pela pobreza, onde é perceptível a alta taxa de mortalidade infantil, geralmente, a infância é percebida "como um estágio isolado de desenvolvimento [...]. Se a infância é definida em termos de falta de responsabilidade, existem muitas sociedades em que mal se pode dizer que ela exista" (Hunt, 2010, p. 93). Notamos a complexidade da questão, a qual traz em si uma problemática que vai além da idade cronológica do sujeito. No que se refere aos livros para crianças, Hunt observa que estes são remetidos ao público infantil conforme a classe social em que elas estão inseridas.

Dessa maneira, a definição da infância não é estável e muda conforme os interesses culturais, políticos e ideológicos. A infância, hoje, é distinta da infância do passado. A infância na Grã-Bretanha é diferente da do Brasil. A infância do sertão nordestino é diferente da de São Paulo. O ponto em comum pauta-se na fantasia, no brincar e na dependência de um adulto que as insira no mundo civilizado. Hoje, no século XXI, as crianças, legalmente, devem ser protegidas, amparadas e respeitadas pelo adulto; no Brasil, especificamente, afirma o Estatuto da Criança e do Adolescente, no capítulo I: "A criança e o adolescente têm direitos à proteção à vida e à saúde, mediante a efetivação de políticas sociais públicas que permitam o nascimento e o desenvolvimento sadio e harmonioso em condições dignas de existência" (Brasil, 2010, p. 13). No entanto, sabemos que estamos diante de paradoxos e contradições.

Percebemos que o cuidado e o rigor são imprescindíveis e necessários para avaliarmos como se dá a constituição da infância, nos livros voltados para o público em questão. Segundo Peter Hunt, lidamos com definições extremamente abertas e variáveis, sobretudo quando pensamos a infância, o leitor e a literatura. Nos textos literários e plásticos selecionados por nós, observamos que a infância, constituída entre letras, trações, pincéis e cores, dialoga com os direitos estabelecidos pela legislação: a criança brinca e se relaciona com os seus pares, num espaço que lhe confere criatividade e dignidade de ser. Pensamos que se trata do encontro com a criança, mesmo que o adulto 
deixe escapar a criança que existe dentro dele. Todavia, é imperioso lembrar as crianças excluídas do universo da fantasia e da imaginação.

\section{Considerações finais}

Poesia é a descoberta das coisas que eu nunca vi.

Oswald de Andrade

Apresentamos alguns títulos e possíveis leituras, considerando a multiplicidade de textos literários de qualidade, editados pelas inúmeras editoras brasileiras, como também refletimos sobre a definição da infância, tendo em vista sua complexidade, de sorte a dar espaço apenas a alguns apontamentos, porque a questão exige uma maior reflexão, inclusive no que diz respeito à relação entre infância e literatura. Compreendemos que a "ideia contemporânea que temos de criança como um ser em desenvolvimento está longe de ser universal, tanto em termos culturais quanto históricos" (Pacheco, 2012, p. 43), uma vez que a criança passa a ser vista como "objeto de estudo da medicina, da pedagogia, da psicologia, do direito etc., não existe a priori como um dado da realidade; antes, trata-se de uma construção criada ao longo das transformações socio-históricas e econômicas que foram se dando no mundo ocidental" (Pacheco, 2012, p. 43), desde a Idade Média.

Dessa maneira, compreendemos que a sociedade contemporânea está permeada pela complexidade social, verificando o "controle internalizado sobre os corpos e a subjetividade que parece acirrar cada vez mais a distância entre crianças e adultos" (Pacheco, 2012, p. 54). Nessa linha de raciocínio, James, Jenks e Prout assinalam, no texto "O corpo e a infância": "O que distingue a criança do adulto é entendido como a prática e o desempenho bem-sucedidos de um controle internalizado, até mesmo inconsciente, sobre o corpo e as suas funções" (James, Jenks e Prout, 1999, p. 225). Ou seja, as crianças "que ainda não aprenderam as técnicas específicas (e historicamente variáveis) de controle social corporal são incivilizadas em termos culturais" (James, Jenks e Prout, 1999, p. 225). A questão sobre a infância dá abertura a uma série de discussões.

Por isso, implicitamente, apropriamo-nos da metáfora de Umberto Eco, presente no texto Seis caminhos pelo bosque da ficção (1994): "Vamos a um bosque passear. Se não somos obrigados a sair correndo para fugir do lobo ou do ogro, é uma delícia nos demorarmos ali, contemplando os 
raios do sol que brincam por entre árvores e salpicam as clareiras" (Eco, 1994, p. 56). Daí o caminho escolhido dentre tantos e a importância de examinar e analisar a constituição do objeto por nós selecionado.

Os livros de literatura, constituídos por uma organização linguística metafórica, polissêmica e estética, destinados ao público infantil e juvenil, oferecem diferentes situações do cotidiano, as quais são problematizadas e promovem um repensar sobre a vida, o tempo e a história, sobretudo pelo fato de que o leitor faz parte da constituição da obra. Os leitores podem experimentar as mais diversas situações na relação com as personagens fictícias que perambulam no universo literário, uma vez que sentir a experiência alheia através das letras provoca um olhar diferente sobre si e o mundo. Iser assinala: "A literatura simula a vida, não para retratá-la, mas para permitir ao leitor que dela participe. Ele pode sair de seu próprio mundo e entrar em outro onde pode viver extremos de prazer e dor sem ser envolvido em quaisquer consequências" (Iser, 1999, p. 42). Nessa perspectiva, participar do mundo ficcional de Manoel de Barros e Selma Maria Kuasne e contemplar as telas de Candido Portinari leva-nos a experimentar, aprender e reconhecer uma forma de ser.

Deparamo-nos com os pincéis e as letras, as cores e os traços, a forma e a imagem, a palavra e a linha, traduzindo as relações metaliterárias, a criatividade, a invenção, o brincar, a fantasia, as relações interpessoais, a infância, os sentimentos arcaicos, a memória e tantos outros temas que podem ser percebidos nesse universo. Paralelamente ao objeto artístico e estético, apropriamo-nos de estudiosos de diferentes áreas de conhecimento, os quais discutem a infância e o brincar, a fim de conduzir e nortear a nossa leitura. Sabemos que experimentar o objeto de arte provoca uma mudança interna, que se projeta na realidade imediata; por conseguinte, pode provocar mudanças não apenas internas, mas também no espaço em que estamos inseridos.

$\mathrm{O}$ ato de ler letras ou pinturas permite ao leitor construir sonhos, experimentar fantasias, descobrir outros universos, refletir e vivenciar experiências alheias. Além disso, faz-nos reconhecer que vivemos numa cultura digitalizada, globalizada, diversa na condição social e econômica, onde há drogas de natureza diversa e grupos mercadológicos manipuladores e abusivos, em todos os sentidos. Há uma intoxicação imperceptível que cerceia a sociedade. Portanto, faz-se necessário o encontro silencioso com as palavras e as cores. É necessário 
pensar a infância e a sua condição atual. A infância é um paradoxo - e a discussão se abre para outros olhares.

\section{Referências}

AGUIAR, Vera Teixeira; CECCANTINI, João Luís (Org.) (2012). Poesia infantil e juvenil brasileira: uma ciranda sem fim. São Paulo: Cultura Acadêmica.

ANDRADE, Carlos Drummond de (2011). Verbo ser. In: FERRAZ, Eucanaã (Org.). A lua no cinema e outros poemas. São Paulo: Companhia das letras.

BARROS, Manoel (1999). Exercícios de ser criança. Bordados de Antônia Zulma Diniz, Ângela, Marilu, Martha e Sávia Dumont sobre os desenhos de Demóstenes. São Paulo: Salamandra.

BOSI, Alfredo (2000). O ser e o tempo da poesia. São Paulo: Companhia das Letras.

BRASIL (2010). Estatuto da criança e do adolescente. Brasília: Câmara dos Deputados.

CANDIDO. Antonio (1995). Vários escritos. 3. ed. São Paulo: Duas Cidades.

COELHO, Nelly Novaes (2000). Literatura infantil: teoria, análise, didática. São Paulo: Moderna.

FERREIRA, Aurélio Buarque de Holanda (1993). Novo dicionário Aurélio de língua portuguesa. Rio de Janeiro: Nova Fronteira.

ECO, Umberto (1994). Seis passeios pelos bosques da ficção. Tradução de Hildegard Feist. São Paulo: Companhia das Letras.

FREUD, Sigmund [1915-1916] (1996). Conferências introdutórias sobre psicanálise (Parte III). In: FREUD, Sigmund. Obras completas: conferências introdutórias sobre psicanálise. Rio de Janeiro: Imago. v. 16.

GREGORIN FILHO, José Nicolau (2009). Literatura infantil: múltiplas linguagens na formação de leitores. São Paulo: Melhoramentos.

HUNT, Peter (2010). Crítica, teoria e literatura infantil. Tradução de Cid Knipel. São Paulo: Cosac Naify.

ISER, Wolfgang (1999). O ato da leitura: uma teoria do efeito estético. Tradução de Johannes Kretscmer. São Paulo: 34. v. 2.

JAMES, Alison; JENKS, Chris; PROUT, Alan (1999). O corpo e a infância. In: KOHAN, Walter Omar; KENNEDY, Duncan (Orgs.). Filosofia e infância: possibilidades de um encontro. 2. ed. Petrópolis: Vozes. 
KETZER, Solange Medina (2003). A criança, a produção cultural e a escola. In: JACOBY, Sissa (Org.). A criança e a produção cultural: do brinquedo à literatura. Porto alegre: Mercado Aberto.

KUASNE, Selma Maria (2009). Um pequeno tratado de brinquedos para meninos quietos. Ilustrações de Anne Vidal. São Paulo: Peirópolis.

PACHECO, Ana Laura Prates (2012). Da infância de fantasia ao infantil na infância: a direção do tratamento na psicanálise com crianças. São Paulo: Annablume.

PAES, José Paulo (2001). Vejam como sei escrever. São Paulo: Ática.

SOUZA, Vera Cristina Chagas Correa de (2011). Defesa e viver criativo: um estudo sobre a criatividade nas obras de S. Freud e D. W. Winnicott. Curitiba: Juruá.

TUCKER, Nicholas (1997). What is a child?. Londres: Fontana; Open Books.

WINNICOTT, Donald Woods (1975). O brincar e a realidade. Tradução de José Octávio de Aguiar e Vanede Nobre. Rio de Janeiro: Imago.

WINNICOTT, Donald Woods (2005). Tudo começa em casa. Tradução de Paulo Sandler. 4. ed. São Paulo: Martins Fontes. (Psicologia e Pedagogia.)

ZILBERMAN, Regina (2003). A literatura infantil na escola. 11. ed. rev. atual. e ampl. São Paulo: Global.

ZILBERMAN, Regina; LAJOLO, Marisa (1986). Um Brasil para crianças - Para conhecer a literatura infantil brasileira: história, autores e textos. 4. ed. São Paulo: Global. (Série Crítica e teoria literária.)

Recebido em setembro de 2014.

Aprovado em fevereiro de 2015.

\section{resumo/abstract}

\section{"Tratado" e Exercício de ser criança: a infância entre versos, rimas e tintas}

Penha Lucilda de Souza Silvestre

Alice Áurea Penteado Martha

A obra de arte, de modo geral, consiste em um evento significativo, visto que o leitor pode vivenciar diferentes mundos ficcionais, como também recuperar e articular as redes intertextuais, no ato da leitura. Assim, há a possibilidade de 
repensar a sua própria experiência e as condições sociais em que a criança está inserida. Nesse sentido, o nosso objetivo é realizar um percurso no universo poético, a partir da leitura dos textos Exercício de ser criança (1999), de Manoel de Barros, e Um pequeno tratado de brinquedos para meninos quietos (2009), de Selma Maria Kuasne, associando-os à produção plástica de Candido Portinari "Meninos soltando pipa" (de 1932), "Crianças brincando" (de 1938) e "Meninos brincando" (de 1955). Com efeito, essas obras nos permitem repensar como se dá a representação e a constituição da infância na arte e entendê-la nas tramas da poesia e da pintura, como também o ato de brincar, em um processo dialético.

Palavras-chave: infância, poesia, artes plásticas, Manoel de Barros.

\section{"Tratado" and Exercício de ser criança: childhood amid verses, rhymes and paints}

Penha Lucilda de Souza Silvestre

Alice Áurea Penteado Martha

The work of art, in general, consists of a significant event, considering the reader can experience different fictional worlds, as well as retrieve and articulate the intertextual networks in the act of reading. Thus, there is the possibility of rethinking one's own experience as well as the social conditions in which the child is inserted. In this sense, our objective is to perform a journey through the poetic universe from the reading of the texts Exercício de ser criança (1999), by Manoel de Barros, and Um pequeno tratado de brinquedos para meninos quietos (2009), by Selma Maria Kuasne, associating them to the paintings by Candido Portinari, 'Boys flying kites' (1932), 'Children playing' (1938) and 'Boys playing' (1955). Indeed, these pictures enable us to rethink how the representation and the constitution of childhood in art are conceived and to understand them in the weaving of poetry and painting, as well as the act of playing, in a dialectical process.

Keywords: childhood, poetry, fine arts, Manoel de Barros. 